\title{
Online Shopping Behavior Among University Students: Case Study Of Must University
}

\author{
Guled Aden Farah \\ Malaysia University of Science and Technology (MUST) \\ Mushtaq Ahmad \\ Tenaga Nasional University (Uniten) Malaysia Kajang
}

Hassan Muqarrab

School of Business Administration, Asia Pacific University Malaysia

\author{
Jamshid Ali Turi \\ School of Business Administration, University Pahang Malaysia \\ Dr. Shahid Bashir \\ Faculty o Management Sciences Szabist Islamabad, Pakistan
}

\begin{abstract}
The goal of the research is to identify and explore most commonly purchasing products online also influencing factors on the online buying behavior of the MUST university students. Functionality, privacy, trust, firm reputation and perceived value are the major influencing factors on consumer buying online behavior. Quantitative study approached has been adopted in this study and total 100 questionnaire samples have been distributed among MUST university business faculty students. The findings indicated that about $99.0 \%$ MUST students are involved in online purchasing and most computer/electronic/ mobile are the common products purchased online. The relationship and data reliability of the influencing factors are significantly reliable and has significant relationships which justify the study hypothesis. Study concluded that among the influencing factors functionality of the web vendors ranked high importunacy followed by privacy, perceived value, firm reputation and trust. The lower ranking of trust is indicating that major respondents group feels uncomfortable or unsafe while trusting on the web vendor.
\end{abstract}

Key Words: Online Shopping Behavior, University Student, Influencing factors of online shopping

\section{INTRODUCTION}

The growth of internet technology has found strong impact on global business. The internet created new environment of e-commerce and has provided opportunities to connect busing through internet across worldwide (Alkailani \& Kumar, 2011). The usage of internet has increased due to it significant tools of fast information delivery to the users also providing more choices of browsing in a shortest possible time. Today, internet is use for several purposes among online shopping is populace. The online shopping open new window for the business where is known business-to-consumer (B2C) where individual benefits using internet technology to buy and sell products electronically (Masoud, 2013).

According to George, (2002) the birth of internet is the revaluation of electronic technology and offers consumers more information of purchasing products by giving more choices where 
in the past was not possible and consumer has spent days to look in the market. The statistical sales purchase figures from e-commerce or online shopping has drastically grown from US695 Billions dollars in 2013 to US840 Billion dollars in 2015. It is further expected to increase up to US1500 Billion dollar in 2018 and the periodically increment in the e-commerce business indicated significant potential in online marketing business (Kearney, 2015). The successful online markets operator eBay, Amzaon, Alibaba, Groupon etc have set an example for others to transform the current shape of the business from brick and mortar to brick and click. The survey study revealed that $67.0 \%$ Malaysian plan to purchase online air tickets which is the $3^{\text {rd }}$ highest online air tickets buying, 64.0\% reserved hotel rooms through internet and 58.0\% Malaysian would purchase online event tickets such as movies tickets etc (Chen et al., 2015). Where, Malaysia is ranked $3^{\text {rd }}$ for online travel tickets, $2^{\text {nd }}$ for hotel room reservation there other products online selling found lower such as electronics, grocery etc.

The online shopping required more customer intention compare to purchasing physically (Chowdhury \& Ahmad, 2012).Although, the rapid growth of online shopping market is the optimistic for the future growth but negative aspects arose in conventional shopping method. Lack of visual contact or physical existence of the product the trust related factor among consumer is highly dominated in online shopping and discourages method of online shopping (Lim et al., 2016).

According to Masoud, (2013) online shopping model is strongly based on the consumer trust since security and privacy of the customer become an imperative. The consumer behavior is critical to decode during transaction because of consumer contribution is not exist.

According to the study internet usage and online shopping are most common in the university age 18-30 years old students even though they do not have sufficient funds for shopping but the university students found on the top listed using internet and has great intention towards online shopping (Edmunds et al., 2010). In the developed countries individual intention and behavior of online shopping is widely studied but lack of studies counted in developing country like Malaysia where online shopping is getting popularity among university students. This research study will keenly focus on Malaysia University of science and technology student's behavior of online shopping and the impacting factors or barriers on online shopping. The objectives of the study are Malaysian university student involvement in online shopping; most common purchasing products among the Malaysian students and influenced of the Privacy, Trust, Functionality, Firm reputation and Perceived value on the Malaysian University student's online shopping behaviour.

\section{LITERATURE REVIEW}

\section{Online Shopping in Malaysia}

The internet was initiated to use in Malaysia in 1995. The survey study was conducted by MIMOS and Beta Interactive services in 1995 showed that $2.0 \%$ population has access to the internet, where data was explained out of 20 million people 20 thousand people has access to the internet in 1995 (Beta Interactive Services, 1996). The number of internet user has seen grown from $2.0 \%$ in 1995 to $2.6 \%$ in 1998.

According to Salman et al., (2013) remarkable selling of computer has noted in 2000 where it was low in 1998 further, energy, communication and Multimedia ministry has reported that in the year of 2000 total $7.0 \%$ population subscribe internet compare to past years where it was $2.6 \%$. Resent statistics of internet subscriber in among native found $72 \%$ (Salman et al., 2013) The online shopping has started late in Malaysia because of the late recognition of internet in the local market also the trend towards using internet. The major use of internet in Malaysia is 
for entertainment and communication rarely use for enterprise or e commerce business (John \& Jacki, 2001). In addition, the utilization of internet is not as popular for online transaction in Malaysia as it is in the Europe and the US. Study revealed that about all internet users like to visit online shopping store but in fact small group is yet going for online shopping. According to John \& Jacki, (2001) only 4.0\% adult done online shopping till 2001 while current study of Nielson stated that Malaysia enable to place in top ranking for online shopping where 6 out of 10 use internet for online shopping which is recorded drastically high figure in online shopping market.

The current online shopping figure stated by Malaysian Master Card survey, (2012) found that $67.0 \%$ people have done online shopping in 2011 and it is $12.0 \%$ higher than past year. The confidence level of Malaysian towards online shopping has been increased from $36 \%$ in 2011 to $39.0 \%$ in 2012. The intent of online shopping among Malaysian is found lower as compare to other south East Asian countries. Among the top advantages of the internet and online shopping has removed the barrier of limited time and distance cover to go for shopping. Most of the companies has reached to the single click option from home just make an order they will deliver on door step which not only save the time also the product available on long distance can be in your access.

The online retailer should have understanding of consumer demands so they can play role and compete in the market (Chen et al., 2009). Additionally, the behavior of online shoppers hard to predict but by maximizing advantage and reduce the threats can motivate the online buyers for shopping.

\section{Online Shopping and Consumers Behaviors}

Kuester, (2012) defined consumers Behaviors as the method used by the individual or groups to select any product or services, experience or ideas to satisfy their needs and their long lasting impact on the consumer and society. The study of consumer behavior was new till late 1960s. The study of consumer behavior was taken from other disciplines such as economics, marketing and behavioral science. Additionally, the concept of vastly study of consumer behavior was created in psychology, social science where individual and groups studies on the human nature, behavior and attitude was conducted (Smith and Rupp, 2003). Thus, since penetration of technology and business trend has changed to online the behavior is important to study. In the era of information technology internet has given and open new window for the world to using internet technology to buy and sell online products where physical involvement is not an important. The online shopping business is not something secret of sale products therefore it is essential to analysis consumers behaviors towards products shopping and payment online because there is not physical interaction between them. Nazir et al., (2012) stressed in his study to analysis and understand the consumer behaviors. The relationship between online selling products and their marketing strategies with the behavior of consumer is strongly bonded. In the past many research studies has been talked about online consumer behavior and the impacting factors. Conversely, since individual behavior is different from others so further research has suggested (Constantinides, 2004).

The consumer adoption of internet technology has been seen higher but internet online purchasing is still far from the target where different commercial agencies have set. Therefore, online consumer is significantly important to study and growing concern from the consumers. Anderson \& Srinivasan (2003) categorized the individual online shopping drive into three groups; the first group indicated perceived risk on web channel, online shopping advantages and consumer experience, service quality, trust. The second group is risk minimization; product and website feathers and the last group stated the consumer's behaviors. Consumer 
shopping behavior is driven by demographic variable, computer and internet knowledge and psychological variable strongly matters. Kotler \& Armstrong, (2010) demonstrated that the buyer's perception of the shopping online is influenced by several parameters among online advertisement on web links divert his mind to do online shopping.

\section{Factors affecting Online Shopping Consumer Behaviors}

There are several factors directly or indirectly affecting the online shopping consumer behavior each is explained below.

\section{E-Satisfaction}

Lin (2003) states that for organizations which manage online administrations, keeping in mind the end goal to be affirmed and acknowledged by the clients, they have to give the best conveyed esteem so customers might consider it to be point of preference and stay faithful to them. Organizations can quantify this quality by taking a gander at consumer loyalty, and elements that influence this fulfillment are: consumer needs, esteem and cost. Mostaghel (2006) contends that highlights shopper fulfillment as crucial to increase better money related execution of administrations in organization, which is the second most vital thing for them, subsequent to picking up a benefit. Organizations saw the quick improvement of innovation as an opportunity to accomplish consumer loyalty and reliability much simpler and with lower expenses.

\section{Trust and Online Risk}

Trust, as expressed by Gommans et al. (2001) is another essential thing is purchaser's internet purchasing conduct, and in their e-reliability. Trust is associated with security. Purchaser can't see item in individual while he is requesting it, and can't investigate salesman's eyes while doing that, so it is essential for organizations to fabricate trust among their buyers keeping in mind the end goal to stay away from vulnerabilities. Steadfastness and brand trust when all is said in done can help with overcoming and beating some Internet drawbacks. He additionally recognized that purchaser's trepidation of online misrepresentation (Visa extortion, nonconveyance of item) is the one of the significant causes why they are not utilizing e-business, every now and again. Anderson and Srinivasan (2003) anticipate that apparent danger is identified with customers' apprehension of losing of a few exchanges which are done on the web. In any case they likewise relate hazard as the possibility of losing something while acquiring or expending the item or administration.

\section{E-Loyalty}

The reliability speaks to solid connection in the middle of brand and client. That solid connection is showed through enthusiastic connection that joins customer's congruity of acquiring and utilization. Gommans et al. (2001) said that e-reliability can be communicated as store loyalty\| which implies that purchasers are consistently going to stores and purchasing things from same brand. He likewise characterizes client dedication as a time when purchaser show and rehash purchasing conduct which have positive nature identified with item supplier, and they are rehashing this activity always.

E reliability is about quality client support, on-time conveyance, convincing item presentations, helpful and sensibly estimated dispatching and taking care of, and clear and dependable security policies.(Gommans et al., 2001) Reichheld and Schefter (2000) showed three preferences of e-dedication. To begin with of them which are most vital and extremely costly is to get faithful client and to keep them steadfast later on. Second, faithful clients devour more than switchers which signs that they will spend more cash later on than the others. The last and however vital one is faithful clients normally propose and recommend non-steadfast 
buyers to purchase in a specific store or brand, so this is circumstance when steadfast clients are utilizing verbal correspondence.

\section{Online Services}

As expressed by Cheung and Lee (2005) in their study, instrument that is utilized for measuring buyers' desires and attention to administrations is called SERVQUAL, which contain five measurements: tangibles, unwavering quality, responsiveness, affirmation and compassion. Tangibles and unwavering quality relates with data and administrations quality offered to client. Responsiveness identifies with reactions from stores, when costumers have issues or inquiries in regards to item. Affirmation identifies with empowering trust and certainty to clients, and demonstrates that each operation inside of organization is finished by individuals who are masters in that field, and sympathy identifies with making care, and giving specific individual consideration regarding clients.

\section{Perceived Value}

Perceived Value is basically the result of showcasing exercises and is the main segment in relationship promoting. Research demonstrated that apparent quality is immediate and particularly is connected with fulfillment. In this way, clients might insightfully consolidate their view of what they get (advantage) and what they needed to yields for them to get a distinct administration. Furthermore, Hsin\& Wen, (2008) additionally recommended that apparent quality is the hugest indication of procurement goal. In the event that a buy gave an abnormal state of worth, this would expand the customer's level of repeat to make buy later on. As standard exchange, Guenzi et al. (2009) found that items esteem discernments encourage the effect of store natural signals and store decision criteria on store support goals. In Malaysia, Study concentrated on the part of the two ideas in data frameworks (ISs) acknowledgment by businesspersons which was observed to be powerful. Seen usability with regards to this exploration alludes to the degree to which a client trusts that internet shopping will be free of effort.

\section{Firm reputation}

According to Hsin \& Wen (2008), firm reputation can be defined as customers' perceptions on how well a firm takes care of customers and is genuinely concerned about their welfare. In addition, Hsin \& Wen (2008) revealed that excellent reputations provide firms with a "buffering effect", protecting them from some of the negative repercussions of failure. He opined that the reputation of a firm watered-down the relationship between failure severity and satisfaction, lowered designations of controllability and stability, and led to higher repurchase intentions following service failures. Attributions of controllability and stability were related only to repurchase intentions; satisfaction did not fully facilitate these relationships. Given these previous research findings, it is likely that a good firm reputation will also lead to greater online repurchase intentions.

\section{Privacy}

Privacy denotes the extent to which an online shopping web site is prove to be safe and safeguards the shoppers' information. The capacity of the new technologies' has grown in terms of information processing, added to its complexity, makes privacy considerably a vital issue of concern (Monsuwe et al., 2004).

\section{Functionality}

Functionality is to do with the degree to which a website offers adequate information about the products/services being advertised (Law and Bai, 2008). Functionality of the website as defined by Ujwala \& Vinay (2014) is providing a timely, efficient and effective delivery system 
for online information. A website is possibly the only way an online store connects with its consumers.

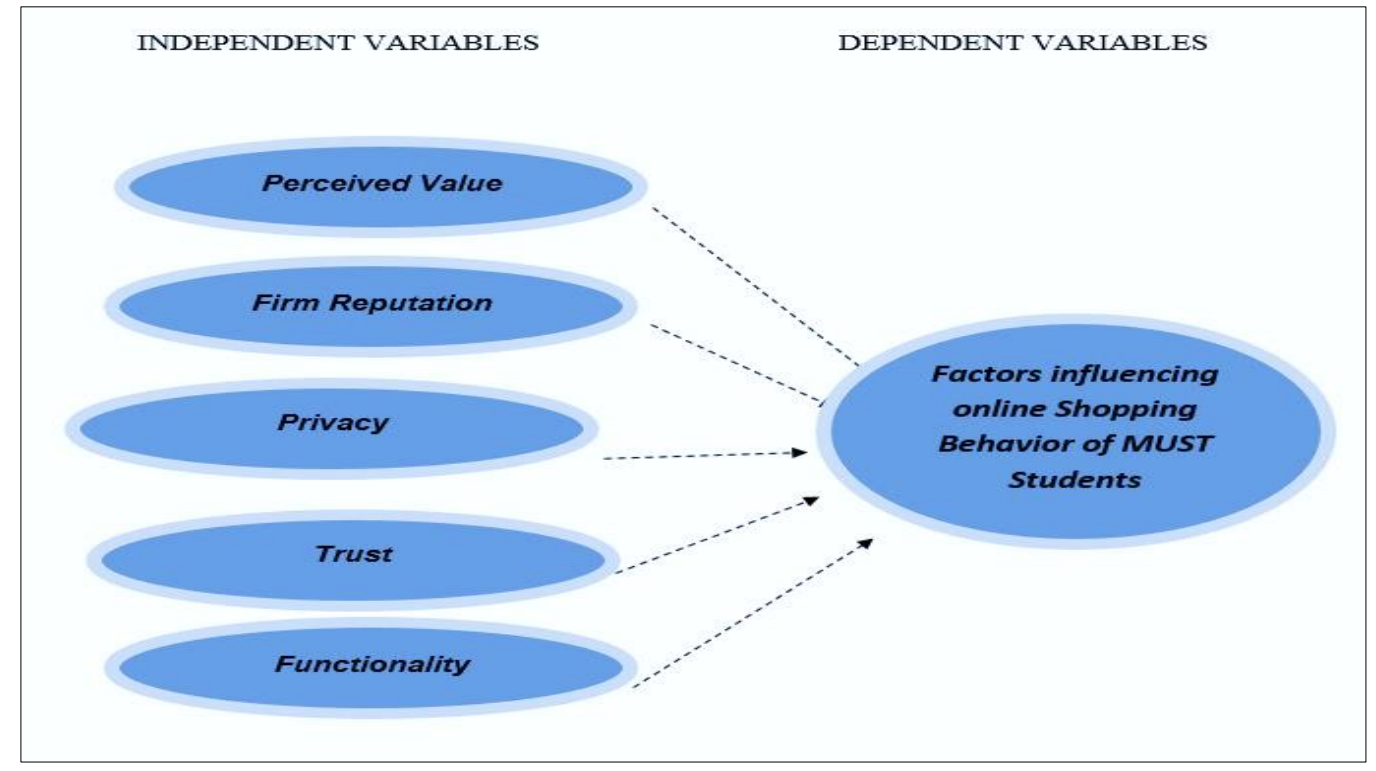

Figure 1: Theoretical Framework

\section{Hypothesis}

There is significant relationship between Perceived value, Firm Reputation, privacy, trust, functionality are the factors influencing online shopping behavior of MUST students to purchase online products.

\section{RESEARCH METHODOLOGY}

The Malaysia University of Science and Technology (MUST) is a comprehensive university offering programmers at all levels, from Foundation Sciences to Diploma, Undergraduate (BSc and BBA), Masters and PhD. Based on Krejcie and Morgan's (1970), the sample of the study was distributed as 100 students out of 600 students from MUST. The sample will be distributed to the student with different programs out of total of population size of the study. The adopted approach of the study is quantitative study where questionnaire is designed and will distribute among MUST study to collect the data. The questionnaire is prepared based on the past studies and pilot study was conducted. The collected samples was analyzed by using Statistical Package for the Social Sciences software(SPSS) software which is convenient to use and fast to get the results. Frequency, descriptive analysis, and to check reliability of the tool internal consistency method using SPSS by finding Cronbach's alpha value lastly correlation factors was determined.

\section{RESULTS AND DISCUSSION}

Findings of the demographic analysis is shown in Table 1 and is indicated that most of the respondents are male students, age 20-25 years old and bachelor degree program students are the highest respondents, about $99.0 \%$ has browsed for products online but $84 \%$ claimed to purchase the online products. Frequency of online shopping purchase shows $32 \%$ annually and computer/electronic and mobile products are most widely purchased through online shopping among MUST university students. 
Table1: Demographic Analysis

\begin{tabular}{|l|l|c|c|}
\hline Description & Variables & Frequency & $\begin{array}{c}\text { Percentage } \\
\text { (\%) }\end{array}$ \\
\hline Gender & Male & 51 & 51 \\
& Female & 49 & 49 \\
\hline Age (Years) & 19 or under & 04 & 4.0 \\
& $20-25$ & 72 & 72 \\
& $26-30$ & 22 & 22 \\
& 31 and above & 02 & 2.0 \\
\hline Respondents highest qualification & Foundation & 07 & 07 \\
& Diploma & 12 & 12 \\
& Bachelor degree & 52 & 52 \\
& Master degree & 29 & 29 \\
\hline Have you ever searched for a & Yes & 99 & 99 \\
product on the internet? & No & 01 & 01 \\
& & 84 & 84 \\
\hline Have you ever purchased a & Yes & 16 & 16 \\
\hline product on the internet? & No & 3 & 3 \\
\hline How frequently do you purchase & Weekly & 27 & 27 \\
online? & Monthly & 32 & 32 \\
& Annually & 22 & 22 \\
& Once every year & 16 & 16 \\
\hline From what product category was & Missing System & Clothing/Shoes/beauty & 11 \\
your last Internet purchase? & Computers/electronics/Mobile & 54 & 54 \\
& Pets/ Gardening/ Hobby items & 06 & 06 \\
& Others & 13 & 13 \\
& Missing System & & 16 \\
& & & \\
\hline
\end{tabular}

\section{Data Reliability Analysis}

Table 2.0 summarized the Cronbach $(\alpha)$ Coefficient of Reliability. The outcomes suggest that the Cronbach $\alpha$ coefficient for all the variables is within the range of 0.685 to 0.848 . Moreover, the aggregate Cronbach $\alpha$ coefficient for all the variables was 0.797 . Generally accepted social science cut-off is that Cronbach's alpha should be 0.70 or higher for a set of objects to be measured in a scale. In another studies numerical value of the standard data reliability is ranging from 0.70-0.95. Thus, this survey data results are reliable. The findings shows that functionality using internet and online shopping found highly reliable of cronbach $\alpha$ coefficient value 0.791 . The cronbach $\alpha$ coefficient value indicating for the variable privacy 0.846 and the value is higher than bench mark 0.70 . This indicated that privacy of online shopping related is highly reliable. Furthermore, third highly reliable variable trust has cronbach $\alpha$ coefficient value of 0.842 also highly reliable. In contrast firm reputation and perceived value variable shows cronbach $\alpha$ coefficient slightly lower than 0.70 which might be the cause of lower number of items or poor interrelation among the items. 
Table 2: Cronbach $\alpha$ Coefficient of Reliability

\begin{tabular}{lcc}
\hline \multicolumn{1}{c}{ Variable } & $\begin{array}{c}\text { Cronbach } \boldsymbol{\alpha} \text { coefficient } \\
\text { for each variables }\end{array}$ & $\begin{array}{c}\text { Aggregate Cronbach } \boldsymbol{\alpha} \\
\text { coefficient }\end{array}$ \\
\hline Functionality & 0.791 & \\
Privacy & 0.846 & $\mathbf{0 . 7 9 7}$ \\
Firm Reputations & 0.685 & \\
Perceived Value & 0.698 & \\
Trust & 0.842 & \\
\hline
\end{tabular}

\section{Descriptive Statistics \\ Functionality}

Table 3 shows the descriptive statistic of variable functionality. Under the variable functionality of online shopping and in the response mean and std deviation is determined and each item based on obtained mean and std deviation are; The web linkage to the information should be easy and facilitate the customer demand has (Mean and std. deviation= 4.22; 0.785); The internet provide the easiest way to scan the information customer want is (Mean and std. deviation $=4.08 ; 0.860$ ); I would be more likely to shop on the Internet if the web site was easy to use (Mean and std. deviation= 3.850; 0.946); I would most likely to purchase if a website has easy titles to understand on each page that I access (Mean and std. deviation= $3.84 ; 0.971$ ).

The findings indicated that the among key objectives of the online shopping design on web linkage should be informative, easy and facilitate the customer demand are the highly ranked followed by the internet usage provide the easiest way of scanning information are the second highly ranked objective of the functionality. On other side the respondents shown agreement with the statement produced and stated respondents will purchase more from the website if easy to understand or another words if the information of the product is clear and easy to search tendency of purchasing might be higher. Likewise, high response has seen for the statement respondents willing or would like purchase the product if the web service provide them easy information.

Table 3: Descriptive statistic of Functionality

\begin{tabular}{|l|r|r|r|}
\hline & N & Mean & Std. Deviation \\
\hline $\begin{array}{l}\text { The internet provides the } \\
\text { easiest way to scan the } \\
\text { information I want }\end{array}$ & 100 & 4.0800 & .86082 \\
$\begin{array}{l}\text { I would most likely to } \\
\text { purchase if a website has easy } \\
\text { titles to understand on each } \\
\text { page that I access. }\end{array}$ & 100 & 3.8400 & .97151 \\
$\begin{array}{l}\text { I would be more likely to shop } \\
\text { on the Internet if the web site } \\
\text { was easy to use }\end{array}$ & 100 & 3.8500 & .94682 \\
$\begin{array}{l}\text { Web linkage to the } \\
\text { information should be easy } \\
\text { and facilities customers } \\
\text { demand } \\
\text { Valid N (listwise) }\end{array}$ & 100 & 4.2200 & .78599 \\
\hline
\end{tabular}




\section{Privacy}

In the online shopping data privacy has significant impact on the behavior of customer. Table 4 indicated the factor affect the privacy of online shopping. In the data privacy the most concerning factor is a good authentication of a website leads me to shopping frequently from a website is ranked highest (Mean and std, deviation $=4.39 ; 0.866$ ). The leading secondly highly impacting factor is I would likely to do online shopping if the level of online security is well taken care (Mean and Std. deviation $=3.25 ; 0.890$ ). I want the ability to access my personal information on the website to ensure that it is accurate and complete is ranked on third showing (Mean and std. deviation $=4.25 ; 0.93$ ). I believe that internet online shopping will secure my personal information (Mean and Std. deviation $=3.32 ; 1.19$ ) shows the respondents are neutral with the statement shows that online web will secure personal information of the customer. This might be the reason of low intention from the customer for doing shopping online using interest technology. Where many believe online web merchant will not able to secure the data or personal information and many skip doing online shopping to purchase the product. The findings of the section shows that customer behavior towards online shopping can be enhance if the privacy ensured from the website to reduce the deception case where customer might loss data as well the credit from his account. Moreover, a good authentication of website leads the customer for shopping online is the motivation factor also access to the personal information on the website to ensure the accurate and complete details.

Table 4: Descriptive Statistics of Privacy

\begin{tabular}{|l|r|r|r|}
\hline & $\mathrm{N}$ & \multicolumn{1}{|c|}{ Mean } & Std. Deviation \\
\hline $\begin{array}{l}\text { I would likely to do online } \\
\text { shopping if the level of online } \\
\text { security is well taken care }\end{array}$ & 100 & 4.3600 & .89020 \\
$\begin{array}{l}\text { A good authentication of a } \\
\text { website leads me to shopping } \\
\text { frequently from a website }\end{array}$ & 100 & 4.3900 & .88643 \\
$\begin{array}{l}\text { I want the ability to access my } \\
\text { personal information on the } \\
\text { website to ensure that it is } \\
\text { accurate and complete } \\
\begin{array}{l}\text { I believe that internet online } \\
\text { shopping will secure my } \\
\text { personal information }\end{array}\end{array}$ & 100 & 4.2500 & .93894 \\
Valid N (listwise) & 100 & 3.3200 & \\
\hline
\end{tabular}

\section{Firm Reputations}

Fire reputation is highly impacting factor on customer in online shopping. The findings extracted in Table 5 shows that customer feelings for shopping from famous online store has (Mean and Std. deviation= 3.15; 1.30). The name value of the firm and the products or services on the web site is important for the students (Mean and std. deviation= 4.08; 0.824). In a general, most internet vendors are competent at serving their customers (Mean and std. deviation= 4.24; 0.96). Famous sites provide quite brandy high quality products/services (Mean and std. deviation=4.12;0.880). In this section, the firm reputation of the online web has been discussed and the vendors serving their customers with competency are ranked on the top. Followed by the vendors providing quality products and services thirdly name of the firm is highly attracted to the customers. In contrast since most of the customer feel insecurity so the level of comfort was shown lower on famous online shopping vendors. 
Table 5: Descriptive Statistics of Firm Reputation

\begin{tabular}{|c|c|c|c|}
\hline & $\mathrm{N}$ & Mean & Std. Deviation \\
\hline $\begin{array}{l}\text { I feel comfortable shopping at } \\
\text { famous online shops } \\
\text { The name value of the firm and } \\
\text { the products or services on the } \\
\text { web site is important for the } \\
\text { students } \\
\text { In a general, most internet } \\
\text { vendors are competent at } \\
\text { serving their customers. } \\
\text { Famous sites provide a quite } \\
\text { brandy high quality } \\
\text { products/services } \\
\text { Valid N (listwise) }\end{array}$ & $\begin{array}{l}100 \\
100 \\
100\end{array}$ & $\begin{array}{l}3.1500 \\
4.0800 \\
4.2400 \\
4.1200\end{array}$ & $\begin{array}{l}1.29782 \\
.82487 \\
.96525 \\
.87939\end{array}$ \\
\hline
\end{tabular}

\section{Perceived Value}

The interlink variable and factors are affecting the behavior of customer during online shopping among perceived value of is the important variable. The findings of the variable are shown in Table 6 indicated that online shopping is useful (Mean and std. deviation $=4.06$; 0.862). I shop at websites which have online features that are customer centered (Mean and std. deviation $=4.05 ; 0.90)$. I tend to compare the value offered by different websites before I make a purchase (Mean and std. deviation $=4.20 ; 0.898$ ). I stick to one website for my online shopping (mean and std. deviation $=3.26 ; 1.16$ ). The findings indicated that customers always tend to compare the price offered by various vendors online is ranked high but on the respond to the usefulness of the online shopping is ranked high too most of the respondents claimed they find online shopping useful. The customer shows priority to the websites concerning features and customers centered are ranked on third important factor. Lastly, reputation or sticking with the same website for online shopping is found lower ranking because customer claimed and always looking for price comparison, fire reputation data privacy etc so these variable intend them to not stick with same website.

Table 6: Descriptive Statistics of Perceived Value

\begin{tabular}{|l|r|r|r|}
\hline & $\mathrm{N}$ & \multicolumn{1}{|c|}{ Mean } & \multicolumn{1}{|c|}{ Std. Deviation } \\
\hline $\begin{array}{l}\text { I find online shopping useful } \\
\text { I shop at websites which have } \\
\text { online features that are customer } \\
\text { centered }\end{array}$ & 100 & 4.0600 & .86246 \\
$\begin{array}{l}\text { I tend to compare the value offered } \\
\text { by different websites before I make } \\
\text { a purchase }\end{array}$ & 100 & 4.0500 & .90314 \\
$\begin{array}{l}\text { I stick to one website for my online } \\
\text { shopping }\end{array}$ & 100 & 3.2600 & .89893 \\
Valid N (listwise) & 100 & & 1.16879 \\
\hline
\end{tabular}

\section{Trust}

In the context of web vendors online shopping trust is significantly important factor. The findings shown in Table 7 are evident indicating that respondents of the study shows neutral response to the questions have been asked in questionnaire. I feel safe with transactions in online shopping sites (Mean and std. deviation=3.58; 1.16). I trust the e-tailor privacy policies specified on their web sites (Mean and std. deviation= 3.37; 1.050). I would purchase if the website provides various types of credit cards for payment (Mean and std. deviation $=3.98$; 0.87). I do not simply trust web shopping because I was conned before (Mean and std. 
deviation $=3.23$; 1.39). Most of the respondents show neutral response to the trust related factors on web shopping which indicating that if web store provide various types of payment options customers shows high interest and ranked highest factor in web store trust. In the contrast, customer does not simply trust on online shopping store because they believe they can be cheated as it happened too many of them where most of them were coned in the past. However, neutral response from the respondents on web store privacy policies shows they are trust on the policies provided by the web store. Since many respondents mentioned in our general survey questions they never purchase product online is the one reason they might be have low trust towards online shopping using web store.

The finding of feel safe with transactions in online shopping sites is showing neutral response which lead the overall result of this section is neutral but if in the future more questions add in this might change the outcome.

Table 7: Descriptive Statistics of Trust

\begin{tabular}{|l|r|r|r|}
\hline & N & Mean & \multicolumn{1}{|c|}{ Std. Deviation } \\
\hline $\begin{array}{l}\text { I feel safe with transactions in online } \\
\text { shopping sites }\end{array}$ & 100 & 3.5800 & 1.16498 \\
$\begin{array}{l}\text { I trust the e-tailor privacy policies } \\
\text { specified on their Web sites }\end{array}$ & 100 & 3.3700 & 1.05078 \\
$\begin{array}{l}\text { I would purchase if the website } \\
\text { provides various types of credit cards } \\
\text { for payment }\end{array}$ & 100 & 3.9800 & .87594 \\
$\begin{array}{l}\text { I do not simply trust web shopping } \\
\text { because I was conned before }\end{array}$ & 100 & 3.9300 & .79157 \\
Valid N (listwise) & 100 & & \\
\hline
\end{tabular}

\section{Hypotheses Testing}

The researcher test hypotheses through analysis of correlations. In this analysis, the researcher first looked in to the regression value $(r)$ whether it is between -1 to 1 . The regression positive value (+1) shows significant relationship among the variable. The multiple correlation test was run using SPSS and the finding is shown in Table 8 indicated the correlation between Perceived value, Firm Reputation, Privacy, Trust and Functionality is significantly strong. The regression value lies in between -1 to +1 , as stated positive regression shows significantly strong relation. The correlation findings shown in the Table 8 indicated that there is significant relationship among functionality, privacy, firm reputation, perceived value and trust towards behavior of MUST university students to do online shopping.

There is significant relationship between Perceived value, Firm Reputation, Privacy, Trust, Functionality are the factors influencing online shopping behavior of MUST students to purchase online product. The findings shown in Table below clearly justify the study hypothesis of significant relationship among various variable is highly influencing on the online shopping behavior of MUST students. The major influencing factor among is the trust where students feel unsafe or uncomfortable while shopping online, firm reputation, product pricing and services including data privacy are all important to them. 
Table 8 : Correlations between Independent variables

\begin{tabular}{|c|c|c|c|c|c|c|}
\hline & & $\begin{array}{c}\text { Functionali } \\
\text { ty }\end{array}$ & Privacy & FR & PV & Trust \\
\hline \multirow{3}{*}{ func } & Pearson Correlation & 1 & $.616^{* *}$ & $.336^{* *}$ & $.293^{* *}$ & .227 \\
\hline & Sig. (2-tailed) & & .000 & .001 & .003 & .942 \\
\hline & $\mathrm{N}$ & 100 & 100 & 100 & 100 & 100 \\
\hline \multirow{3}{*}{ privacy } & Pearson Correlation & $.616^{* *}$ & 1 & $.617^{* *}$ & $.541^{* *}$ & $.205^{*}$ \\
\hline & Sig. (2-tailed) & .000 & & .000 & .000 & 040 \\
\hline & $\mathrm{N}$ & 100 & 100 & 100 & 100 & 100 \\
\hline \multirow{3}{*}{ FR } & Pearson Correlation & $.336^{* *}$ & $.617^{* *}$ & 1 & $.722^{* *}$ & $.498^{* *}$ \\
\hline & Sig. (2-tailed) & .001 & .000 & & .000 & .000 \\
\hline & $\mathrm{N}$ & 100 & 100 & 100 & 100 & 100 \\
\hline \multirow{3}{*}{ PV } & Pearson Correlation & $.293^{* *}$ & $.541^{* *}$ & $.722^{* *}$ & 1 & $.590^{* *}$ \\
\hline & Sig. (2-tailed) & .003 & .000 & .000 & & .000 \\
\hline & $\mathrm{N}$ & 100 & 100 & 100 & 100 & 100 \\
\hline \multirow{3}{*}{ Trust } & Pearson Correlation & .227 & $.205^{*}$ & $.498^{* *}$ & $.590^{* *}$ & 1 \\
\hline & Sig. (2-tailed) & .942 & .040 & .000 & .000 & \\
\hline & $\mathrm{N}$ & 100 & 100 & 100 & 100 & 100 \\
\hline
\end{tabular}

**. Correlation is significant at the 0.01 level (2-tailed).

\section{DISCUSSION}

Table 9 indicated the ranking of independent variables according to their mean and std deviation value. The findings indicated that Trust is ranked with lowest mean value of (Mean= 3.64) which represent the lower trust of the student on online shopping or they do not feel comfortable and safe doing online web shopping. The results further shows high functionality of the internet based web shopping is the ranked top among other mean (Mean $=3.99$ ). Perceived value of the products and services provided by the web store is found on third $\left(3^{\text {rd }}\right.$ )on ranking (Mean= 3.89). Respondent's shows good product pricing and services provided by the web store is highly mean to them. The fire reputation is ranked on fourth mean value (3.79) indicating that web based firm should improve their standard so possibility to attract more customers, here respondent did not affirmed firm reputation. In the meantime firm reputation is the in the third rank. It explains that customers are very careful to choose online vendor to be dealing with to prevent deal with dishonest or disreputable vendors. Lastly the trust is ranked lowest or on the fifth where respondent shows neutral trust on the web store. The online web store should be secured because they are handling with online transaction in case of data leaking to unsafe hand customer can loss and the firm wills loss reputation.

\begin{tabular}{|l|r|r|r|}
\hline \multicolumn{4}{|c|}{ Table 9: Descriptive Statistics of Variable } \\
\hline & Ranking & Mean & \multicolumn{1}{c|}{ Std. Deviation } \\
\hline Functionality & 1 & 3.9975 & .65952 \\
\hline Privacy & 2 & 3.9325 & .83277 \\
\hline Firm Reputation & 4 & 3.7950 & .57680 \\
\hline Perceived value & 3 & 3.8925 & .73706 \\
\hline Trust & 5 & 3.6400 & .84859 \\
\hline
\end{tabular}

\section{CONCLUSION}

The research study has set goals which are linked with research questions and each question is answered using quantitative study. In this part of conclusion each research question is concluded below; 


\section{How frequent MUST university students are involved into the online shopping?}

In the research questionnaire this question is sub divided into several questions and the findings of the question and objective is achieved as result is drawn in Table 1 . This study concluded that $99.0 \%$ MUST student have searched products online using internet, $84.0 \%$ respondents claimed purchased products online form web stores and $32.0 \%$ maximum respondents claimed that involved yearly online shopping, $27.0 \%$ respondents claimed they are involved monthly online shopping. These findings indicated that among small population of $3.0 \%$ is involved in weekly based online shopping and maximum $32.0 \%$ population is involved yearly based online shopping. The study concluded that there is several factors which influenced on the students so they are avoiding online shopping and prefer conventional shopping method but the statically result shown in Table 1 indicated that most of the students are involved did yearly online shopping.

\section{What are the most commonly online purchasing products among MUST university students?}

Refer to the previous findings shown in Table 1 indicated that most of the study population or in other words MUST university have claimed that computer/electronics/software/mobile are the most common products purchased by the MUST university students of about 54.0\% followed by clothing beauty accessories $11.0 \%$ commonly searched and purchased by the study respondents.

\section{What is the factors influenced MUST University student's online shopping behaviour?}

Literature of the study comprehensively studies the affecting consumer behavior factors and among several factors have selected to study in the context of the MUST university students online shopping behavior. Gommans \& Krishnan,(2001); Lin (2003); Mostaghel (2006); Kotler and Armstrong, (2010); contended following influencing factors on the consumer online shopping behavior. The consumer shopping behaviors influencing factor are Functionality; Privacy; Firm reputation; perceived value and Trust have significant impact on consumer online shopping behavior. The correlation of these variable and factors is shown in Table 8 clearly indicating significant correlation among these factors. Further mean and std deviation finding in Table 9 shows that online web store functionality are the top most influencing factors followed by privacy, firm reputation, perceived value and low influencing factor trust. This study concluded that functionality is the most influencing factor which makes the online shopping easy and convenient to the users. The vendors store should be effectively operated by the expert so it does not take long to provide the information or it should be take long time to upload the required information to the customers also clear information shows the high interest to the customers. In contrast, personal data privacy and users access to the personal information is also found on the second influencing factor. Hsin \& Wen, (2008) additionally recommended that apparent quality is the hugest indication of procurement goal. In the event that a buy gave an abnormal state of worth, this would expand the customer's level of repeat to make buy later on. As standard exchange, Guenzi et al. (2009) found that items esteem discernments encourage the effect of store natural signals and store decision criteria on store support goals. Thus the perceived value of the products and services provided by the vendors are significantly important.

Likewise other significant factors influencing on online shopping behaviors of customers among trust has lowest mean which indicated that respondent's shows lower trust on online websites. The findings shows that students are concerning about the trust created by the vendors between customers and services providers is not strong. There should be effective and efficient measurement taken to enhance the trust. Many believes they not feel comfortable when making online transactions to the vendors and they been coned in the past. In online 
business trust is highly measurable factor and which cannot be judged within four questions further investigation with more questions related to the trust should be included so understanding creates between vendors and customers. Trust and data privacy plays an important role in online shopping and both factors are always parallel significant.

\section{RECOMMENDATIONS AND FUTURE STUDY}

Since study has found that $99.0 \%$ of the MUST university students have been searched for online products and $84.0 \%$ is able to purchased products online. This finding is clearly indicated that MUST university student has positive intention towards online shopping. However influencing factors has significant impact on student's online shopping behaviors. There are several factors among functionality, privacy, firm reputation, perceived value and trust found to be the most influencing factors and data results shows the significant relationship among these factors. Based on the study findings recommendation has been made; the gap present in the function of the vendor's web link should always be monitor and quickly solve the problem like server down, web site link down problem in the moment of customer looking for the product information. Author recommended an efficient and effective web site link with all necessary product information available on the website. So the customer will show more confidence also making faster purchase when find the effective and efficient web link.

Date security is always major concern for the customer purchase online products Customers has to uncover banking details to the website so they always worry not be cheated when provide information. The website should protect the customer information by taken proper measurement. Firm reputation is always important to the customers so this is suggested to the online shopping business to provide complete and reliable firm information. Customer will always search for a business that can provide better customer value. The better product and service value will always attract the customer for the product to be purchased online.

\section{Reference:}

Alkailani, M. and Kumar, R. (2011). Investigating Uncertainty Avoidance and Perceived Risk for Impacting Internet Buying: A Study in Three National Cultures. international Journal of Business and Management, 6(5), 76-92.

Anderson, R.E., Srinivasan, S.S., (2003). E-satisfaction and e-loyalty: A contingency framework. Psychol. Mark. 20, 123-138.

Beta Interactive Services. (1996). Malaysian Internet shopping survey, 14 May 1996. Available at: http//www.jaring.my/biz/cybersquare/survey.htm.

Chowdhury, M. S., \& Ahmad, N. (2012). Factors Affecting Consumer Participation In Online Shopping In Malaysia: The Case Of University Students. European Journal of Business and Economics, 5.

Chen, Y. Y., Huang, H. L., Huang, W. N. \& Sung, S. F. (2009). Confirmation of Expectations and Satisfaction with an On-Line Service: The Role of Internet Self-Efficacy. Proceedings of the 2009 International Conference on New Trends in Information and Service Science. Pp: 880-885. DOI: 10.1109/NISS.2009.60

Chen, S., Tan, A., Chong, P. K. (2015, February 13). Pillar of Malaysia's Consumer Spending May Be Weakening. Retrieved June 21, 2015.

Cheung, C.M., Lee, M.K., (2005). Research framework for consumer satisfaction with internet shopping

Constantinides, E. (2004). Influencing the online consumer's behavior: the web experience. Internet Research, 14(2), 111-126.

Edmunds, R., Thorpe, M., \& Conole, G. (2010). Student attitudes towards and use of ICT in course study, work and social activity: A technology acceptance model approach, British Journal of Educational Technology. 43(1), 71-84.

George, J. (2002). Influences on the intent to make Internet purchases. Internet Research 12(2), 165-180.

Gommans, M., Krishnan, K.S., Scheffold, K.B., (2001). From brand loyalty to e-loyalty: a conceptual framework. J. Econ. Soc. Res. 3, 43-58. 
Guenzi, P., Johnson, M.D. and Castaldo, S. (2009). A comprehensive model of customer trust in two retail stores. Journal of Service Management, Vol. 20 No. 3, pp. 290-316.

Hsin Chang, H., \& Wen Chen, S. (2008). The impact of online store environment cues on purchase intention: Trust and perceived risk as a mediator. Online information review, 32(6), 818-841.

John P. and Jackie L.(2000). Drivers and impediments to e-commerce in Malaysia. Malaysian Journal of Library \& Information Science, Vol.6, no.2, December 2001: 1-19

Kearney,A.T. (2015). The 2015 Global Retail E-Commerce Index: Global Retail E-Commerce Keeps On Clicking. Chicago: A.T. Kearney.

Kuester. (2012). Strategic Marketing \& Marketing in Specific Industry Contexts, University of Mannheim, p. 110.

Kotler, P., Armstrong, G. (2010), Principles of Marketing, (13th edition), New Jersey: Pearson Education

Lim,Y.L, Abdullah O. Shahrul N.S. Abdul R.R. \& Safizal A (2016). Factors Influencing Online Shopping Behavior: The Mediating Role of Purchase Intention. Procedia Economics and Finance 35 ( 2016 ) 401 - 410.

Lin, C.C., (2003). A critical appraisal of customer satisfaction and e-commerce. Manag. Audit. J. 18, 202-212.

Masoud, E.Y.(2013). The Effect of Perceived Risk on Online Shopping in Jordan. European Journal of Business and Management www.iiste.org ISSN 2222-1905 (Paper) ISSN 2222-2839 (Online) Vol.5, No.6.

Monsuwe, P., T., Dellaert, C., G., B., Ruyter, K. (2004). What drives consumers to shop online? A literature review. International Journal of Service Industry Management, Vol.15(1), pp.102-121.

Mostaghel, R., (2006). Customer satisfaction: service quality in online purchasing in Iran.

Nazir, S., Tayyab, A., Sajid, A., Rashid, H., Javed, I. (2012), 'How online shopping is affecting consumers buying behaviour in Pakistan?', International Journal of Computer Science Issues, Vol.9(3), pp.486-495.

Reichheld, F.F., Schefter, P., (2000). E-loyalty. Harv. Bus. Rev. 78, 105-113.

Salman.A, Choy A., Amizah W. \& Roslina A. L.(2013). Tracing the Diffusion of Internet in Malaysia: Then and Now. Asian Social Science; Vol. 9, No. 6; 2013 ISSN 1911-2017 E-ISSN 1911-2025 Published by Canadian Center of Science and Education

Smith, A. D and Rupp, W. T.(2003). Strategic online customer decision making: leveraging the transformational power of the Internet. Online information review (27:6) 2003, pp 418- 432.

Ujwala D. \& Vinay K. (2014). A study of factors affecting online buying behavior: a conceptual model. 